\title{
Rekognisi Hak Masyarakat Hukum Adat dalam Konstitusi
}

\author{
Muhammad Dahlan \\ Fakultas Hukum Universitas Brawijaya \\ dahlan@ub.ac.id
}

\begin{abstract}
This article reviews critically the evolution of the regulation of recognition of the rights of indigenous peoples in the Indonesian Constitution through historical and legal perspective. Using the customary law rights recognition theory as developed by constitutionalists on the experience of the struggle of indigenous peoples in several Latin American countries, this article finds the fact that none of the Constitutions in Indonesia fully recognize and protect the rights of indigenous peoples, although it contains elements of partisanship rhetoric. The weak recognition and protection of the rights of indigenous peoples in the Constitution resulted in the state freely using its power to exclude ancestral rights of indigenous peoples on the pretext of state interests. The interpretation of the articles in the Constitution that recognize and protect the rights of indigenous peoples must be based on the spirit of asserting Indonesian unity in diversity and distinctiveness. Without such enthusiasm, there is will more issues relating to derogation or even the elimination of the rights of indigenous peoples.
\end{abstract}

Keywords: indigenous peoples; customary law rights recognition; Indonesian Constitution. 


\section{Muhammad Dahlan}

\section{Abstrak}

Artikel ini mengulas secara kritis evolusi pengaturan rekognisi hak masyarakat hukum adat dalam Konstitusi Indonesia melalui kacamata sejarah dan perbandingan hukum. Dengan menggunakan teori rekognisi hak masyarakat hukum adat sebagaimana yang dikembangkan oleh kaum konstitusionalis atas pengalaman perjuangan masyarakat hukum adat di beberapa negara Amerika Latin, artikel ini menemukan fakta bahwa tidak satupun Konstitusi di Indonesia secara penuh memberikan pengakuan dan perlindungan terhadap hak masyarakat hukum adat, meskipun mengandung unsur retorika keberpihakan. Lemahnya pengakuan dan perlindungan hak masyarakat hukum adat dalam Konstitusi mengakibatkan negara dengan leluasa menggunakan kekuasaannya untuk mengenyampingkan hak turun temurun (ancestral domain) masyarakat hukum adat atas dalih kepentingan negara. Interpretasi terhadap pasal-pasal dalam Konstitusi yang mengakui dan memberikan perlindungan terhadap hak masyarakat hukum adat harus didasari oleh semangat menegaskan persatuan Indonesia dalam keberagaman dan kekhasan. Tanpa semangat demikian, persoalan-persoalan yang berkenaan dengan derogasi atau bahkan penghilangan hak-hak masyarakat hukum adat akan terus terjadi.

Kata Kunci: masyarakat hukum adat; rekognisi hak masyarakat hukum adat; Konstitusi Indonesia.

\section{A. Pendahuluan}

Artikel ini membahas evolusi pengaturan rekognisi hak masyarakat hukum adat (MHA) dalam Konstitusi Indonesia. Pembahasan ini dilakukan untuk mengetahui bagaimana perkembangan pengakuan dan perlindungan hak MHA dalam Konstitusi yang pernah dan masih berlaku. Sejak merdeka tahun 1945 tercatat Konstitusi yang pernah berlaku di Indonesia adalah Undang-undang Dasar Negara Republik Indonesia 1945 (UUD NRI 1945), UUD Republik Indonesia Serikat (UUD RIS), UUD Sementara 1950 (UUDS 1950), dan UUD NRI 1945 setelah amandemen 1999-2002; yang disebut terakhir, dengan nama persis sebelum diamandemen, merupakan Konstitusi yang saat ini berlaku.

Upaya merekognisi hak MHA sesungguhnya telah menjadi 
gerakan transnasional. Gerakan MHA ini bersama aktivis dan akademisi semakin berkembang dan marak karena dua hal. Pertama, penggunaan teknologi informasi komunikasi yang intensif di antara gerakan itu yang menstimulasi perluasan jaringan, kampanye, dan cakupan wilayah dari semula lokal menjadi transnasional. ${ }^{1}$ Kedua, munculnya berbagai instrumen hukum dan kebijakan negara yang diperuntukkan bagi proses eksploitasi sumber daya alam oleh korporasi baik milik negara maupun swasta yang mengakibatkan ruang hidup MHA terampas dalam skala yang sangat masif, sehingga mendorong gerakan penghentian perampasan terhadap ruang hidup itu lewat jalur advokasi internasional.

Beberapa gerakan MHA transnasional dalam merekognisi hak MHA selama ini bisa dikatakan berhasil. Sebagai contoh, aliansi gerakan MHA Ekuador, Bolivia, dan Kolombia selama tahun 19942004 (diakui oleh Perserikatan Bangsa-Bangsa [PBB] sebagai Decade of World's Indigenous People) berhasil mendorong Declaration on the Rights of Indigenous Peoples. ${ }^{2}$ Terpilihnya Evo Morales, seorang pemimpin kelompok petani subsisten dari suku Aymara, sebagai Presiden pada tahun 2005 dan amandemen Konstitusi Bolivia pada tahun 2009, dipandang sebagai kemenangan kolosal karena Konstitusi itu menjadikan MHA Bolivia sebagai subjek hukum yang berdaulat atas ruang hidup, sumber daya, dan identitasnya. ${ }^{3}$ Pada tahun 2016, suatu kepu-

1 Gerakan MHA transnasional merupakan satu dari bentuk gerakan agraria yang dikenal dengan "gerakan agraria transnasional", meskipun pada kenyataannya isu perjuangan yang diangkat antara gerakan agraria transnasional satu sama lain saling beririsan. Di samping perjuangan hak MHA, gerakan agraria transnasional yang muncul dan populer di negaranegara berkembang adalah gerakan petani tradisional seperti $\mathrm{La} \mathrm{Via}$ Campesina yang beranggotakan gerakan petani di seluruh benua Eropa, sebagian Afrika, Jepang, sebagian Eropa Barat, Asia Selatan dan Asia Tenggara (Serikat Petani Indonesia [SPI] menjadi salah satu anggota dari gerakan tersebut).

2 Gerakan MHA Amerika Latin yang mendorong deklarasi PBB itu adalah Movimiento al Socialismo dan Confederacion de Nacionalidades Indigenas del Ecuador yang bermukim di pinggiran gugus pegunungan Andes. Jeffrey R. Webber, Red October Left-Indigenous Struggles in Modern Bolivia (Leiden: Brill, 2011).

3 Konstitusi Bolivia 2009 termasuk konstitusi yang paling lengkap 
tusan politik serupa diumumkan oleh MHA Zapatista di Meksiko, yang akan mengambil jalur perjuangan elektoral-formal dengan tujuan ingin menghentikan berbagai akuisisi lahan pertanian oleh industri pangan Amerika Serikat di Chiapas lewat perjanjian North American Free Trade Agreement (NAFTA) sekaligus juga mengupayakan perlindungan MHA melalui perubahan konstitusi.

Di Indonesia, gerakan serupa muncul melalui Aliansi Masyarakat Adat Nusantara (AMAN), ${ }^{4}$ suatu aliansi progresif yang dibentuk pasca keruntuhan rezim Orde Baru di Jakarta tahun 1999. Gerakan ini mengusung tema populer menuntut rekognisi hak MHA oleh negara. Di antara agenda awalnya pada saat itu ialah mendorong disahkannya UU Desentralisasi Pemerintahan dan UU Hak Asasi Manusia serta menuntut pertanggungjawaban negara atas berbagai ketidakadilan dan marginalisasi terhadap MHA selama periode kekuasaan Presiden Soeharto. Berbagai isu seputar agraria yang diperbincangkaan: konflik perebutan sumber daya, privatisasi lahan, pengambilalihan tanah (land-grabbing), klaim-reclaiming dan sebagainya, dalam perkembangannya telah menyita perhatian gerakan sosial, intelektual organik dan pengamat baik dalam dan luar negeri. ${ }^{5}$

Pada tahun 2012, upaya merekognisi hak MHA di Indonesia

mengatur perlindungan MHA. Nama resminya adalah Constitucion del Estado Plurinacional de Bolivia 2009; plurinasional berarti koeksistensi dua atau lebih kelompok etnis, suku, atau MHA dalam suatu pemerintahan nasional. Angelica T. Nieves, "The Indigenous and the Struggle for Political Representation in Bolivia”, (disertasi, University of South Florida, 2012), http: / / scholarcommons.usf.edu/ etd/ 4183.

4 Pada saat pembentukannya, anggota gerakan MHA yang tergabung dalam AMAN dari Sabang sampai Merauke mencapai 925 anggota. AMAN memperkirakan jumlah penduduk Indonesia yang merupakan MHA mencapai 70 juta jiwa atau sekitar 20 persen dari populasi Indonesia. http: / / www.aman.or.id

5 Ben White menyebut fenomena ini sebagai gelombang gerakan agraria sarjana-aktivis. Ben White, "Di antara Apologia Diskursus Kritis: Transisi Agraria dan Pelibatan Dunia Ilmiah di Indonesia”, dalam Ilmu Sosial dan Kekuasaan di Indonesia, ed. Vedi R. Hadiz dan Daniel Dhakidae (Jakarta: Equinox Publishing, 2006), hlm. 147. Dalam bidang hukum, peranan gerakan MHA di Indonesia bisa diteorisasikan sebagai alternatif bagi penegakan hukum yang tidak semata-mata menekankan pada peran aktif negara, tetapi juga gerakan sosial civil society. 
ditandai oleh putusan Mahkamah Konstitusi (MK) No 35/PUU$\mathrm{X} / 2012$ yang menyatakan teritorialisasi wilayah hutan adat sebagai hutan negara yang diatur dalam UU Nomor 41 Tahun 1999 tentang Kehutanan bertentangan dengan UUD NRI 1945. Putusan penting yang antara lain didorong oleh AMAN ini menandai satu langkah maju dari pertautan antara politik rekognisi dan redistribusi yang dijalankan oleh pelaku gerakan MHA di Indonesia. ${ }^{6}$ Selain itu, beberapa gerakan lain seperti Konsorsium Pembaharuan Agraria (KPA) dan Sayogyo Institute sejak tahun 2012 juga terus mendorong pembahasan Rancangan Undang-Undang Pengakuan dan Perlindungan Hak Masyarakat Adat (RUU PPHMA) di Dewan Perwakilan Rakyat(DPR), kendati tampaknya sampai saat ini masih belum memberikan hasil yang menggembirakan.

Meskipun beberapa capaian tersebut bisa dikatakan berhasil, pada kenyataannya hal itu belum cukup membebaskan MHA dari bentuk-bentuk represi oleh negara dan korporasi. ${ }^{7}$ Sebagaimana dilaporkan Yance Arizona, pada praktiknya pemerintah (daerah) maupun korporasi masih menguasai hutan-hutan adat dengan mengusir MHA dari wilayah mereka. ${ }^{8}$ Berbagai bentuk penyingkiran MHA di Indonesia dilegitimasi oleh produk hukum negara yang sekto-

6 Laskmi Savitri, "Rentang Batas Dari Rekognisi Hutan Adat dalam Kepengaturan Neoliberal”, Jurnal Wacana, 33, 14 (2014), hlm. 62. Lihat pula Diah Pawestri Maharani, "Pembatasan Hak Menguasai Negara oleh Masyarakat Adat dalam Pengelolaan Sumber Daya Air”, Jurnal Arena Hukum, 9, 1 (2016), hlm. 32-52.

7 Laporan Komnas HAM tahun 2015 mencatat terdapat 7.285 pengaduan kasus pelanggaran HAM terhadap masyarakat hukum adat antara tahun 2012 sampai 2014. Sekitar 80 persen di antaranya berkaitan dengan konflik agraria, disusul pengaduan pelanggaran HAM terhadap perempuan dan ketenagakerjaan. Sementara itu, KPA melaporkan bahwa selama tahun 2016 terjadi 450 konflik agraria di seluruh Indonesia dengan luasan wilayah 1.265.027 ha dan melibatkan 86.745 kepala keluarga. Korporasi perkebunan dan kehutanan tetap menduduki peringkat teratas dari konflik agraria yang terjadi. Komnas HAM, Inkuiri Komnas HAM Hak Masyarakat Hukum Adat atas Wilayahnya di Kawasan Hutan; Buku I (Jakarta: Komnas HAM, 2016); KPA, Catatan Akhir Tahun 2016: Liberalisasi Diperhebat, Reforma Agraria Dibelokkan (Jakarta: KPA, 2017).

8 Informasi ini diperoleh dalam wawancara dengan Yance Arizona mengenai reforma agraria di Malang, 10/10/2016. 
ral, yang menunjukkan keberpihakan pada kepentingan modal dan mengandung hukuman pidana yang kejam.

Situasi demikian menimbulkan pertanyaan: mengapa putusan MK hanya mampu mengakhiri sebagian kecil saja dari penindasan yang selama ini dialami MHA; mengapa atas nama "kepentingan nasional" dan "pembangunan", negara melalui instrumen hukumnya mengenyampingkan hak turun temurun (ancestral domain) MHA. Alih-alih memberi perlindungan seluruhnya kepada semua elemen masyarakat termasuk MHA, negara, sebagaimana yang dicurigai oleh Nancy Peluso, justru mendesain untuk mengingkari legitimasi sistem kepemilikan yang ada sebelumnya, mempersepsikan suatu sumber daya alam bukan milik siapa-siapa dan selanjutnya mengklaim kepemilikan sumber daya alam tersebut sehingga bisa ditetapkan peruntukan dan hubungan-hubungan hukum yang baru terhadapnya. ${ }^{9}$ Tidak seperti kasus Evo Morales di Bolivia yang berujung pada penguatan hak konstitusional secara penuh, rekognisi bersyarat (conditional recognition) yang diatur dalam Pasal 18B ayat (2) UUD NRI 1945 dan posisi negara sebagai penguasa atas sumber daya alam sebagaimana diatur dalam Pasal 33 UUD NRI 1945 ditengarai menjadi unsur yang menghalangi pengakuan penuh terhadap hak MHA.

Dalam artikel ini, perlindungan hak MHA akan ditelusuri genealogi pengaturannya dalam Konstitusi Indonesia yang pernah dan masih berlaku. Pada bagian awal dijelaskan terlebih dahulu secara konseptual bentuk perlindungan konstitusional yang dikembangkan oleh beberapa ahli berdasarkan pengalaman di beberapa negara secara komparatif. Tujuannya adalah untuk menetapkan klasifikasi atau kriteria rekognisi hak MHA. Artikel kemudian dilanjutkan dengan pembahasan rekognisi hak MHA di Indonesia pada masa kolonial dan konstitusi yang pernah dan masih berlaku. Dengan begitu, pada bagian akhir akan diketahui apakah rekognisi tersebut sudah sejalan dengan klasifikasi yang ditetapkan sebelumnya.

9 Nancy Lee Peluso, Rich Forest Poor People: Resource Control and Resistance in Java (Hutan Kaya Rakyat Melarat Penguasaan Sumberdaya dan Perlawanan di Jawa, terj. Landung Simatupang (Yogyakarta: Insist Press, 2006), hlm. 13. 


\section{B. Konsep Rekognisi Hak Masyarakat Hukum Adat}

Dalam artikel ini istilah "rekognisi hak masyarakat hukum adat" merujuk pada suatu bentuk pengakuan dan perlindungan terhadap hak MHA melalui konstitusi. Artikel ini juga menggunakan istilah "masyarakat hukum adat", terlepas dari berbagai perdebatan tentang definisi dan istilah yang tepat untuk masalah tersebut. ${ }^{10}$ Dalam bahasa Belanda, istilah MHA merujuk pada istilah rechtgemeenschaap, yang sebenarnya dikaitkan dengan suatu format entitas (entity) namun juga ada yang menerjemahkannya sebagai "masyarakat hukum" atau "persekutuan hukum", sehingga apa yang dimaksud MHA dalam penerjemahan itu diletakkan dalam konteks teritorial maupun genealogis. ${ }^{11}$ Dalam kepustakaan berbahasa Inggris, istilah yang sering ditemukan ialah indigenous peoples dan tribal peoples yang juga digunakan di dalam beberapa kovenan internasional. Meskipun sama-sama diletakkan dalam konteks teritorial dan genealogis, kedua istilah itu baik secara politis maupun hukum memiliki perbedaan yang mendasar. Istilah indigenous peoples, sebagaimana didefinisikan oleh PBB berarti: ${ }^{12}$

Emerged from the colonial experience, whereby the aboriginal peoples of a given land were marginalized after being invaded by colonial powers, whose peoples are now dominant over the earlier occupants. These earlier definitions of indigenousness make sense when looking at the Americas, Russia, the Arctic and many parts of the Pacific. However, this definition makes less sense in most parts of Asia and Africa, where the colonial powers did not displace whole populations of peoples and replace them with settlers of European descent.

Berbeda dari istilah indigenous people, istilah tribal peoples merupakan istilah yang lebih menggambarkan suatu MHA yang tidak memiliki pengalaman kolonisasi. Konvensi ILO 169 tahun 1989

10 Istilah lainnya yang sering digunakan adalah kesatuan masyarakat hukum adat.

11 Pendapat ini dikemukakan oleh Bagir Manan dalam Risalah Perubahan Konstitusi. Naskah Komprehensif Perubahan Undang-Undang Dasar Negara Republik Indonesia Tahun 1945 Buku 4 Jilid 2 (Jakarta: Mahakamah Konstitusi, 2012), hlm. 1356.

12 United Nation, State of the World Indigenous Peoples (New York: United Nation, 2009), hlm. 6. 
mendefinisikannya sebagai berikut: ${ }^{13}$

Tribal peoples is peoples in independent countries whose social, cultural and economic conditions distinguish them from other sections of the national community, and whose status is regulated wholly or partially by their own customs or traditions or by special laws or regulations.

Tujuan hukum rekognisi hak MHA ialah merestrukturalisasi secara positif hubungan antara kekuasaan negara dan masyarakat hukum adat. Di negara-negara koloni merdeka seperti Australia, New Zealand, Amerika Serikat dan Afrika Selatan, hal ini mensyaratkan suatu pengakuan terbuka bahwa negara yang bersangkutan sepanjang periode kekuasaannya telah melakukan pelanggaran, pengabaian, dan pemarjinalan hak masyarakat hukum adat baik secara langsung maupun tidak, termasuk genosida terhadap suku tertentu. Pengakuan semacam ini membutuhkan keberanian, komitmen dan kesukarelaan yang tulus dari negara karena berpotensi mendelegitimasi kekuasaan pemerintahan yang hendak melakukan rekognisi. Hal ini tentu saja berbeda di negara pasca kolonial Asia Tenggara, sebagian Afrika dan Amerika Latin. Di kawasan ini rekognisi MHA bergantung pada kehendak dan komitmen elite nasional yang membentuk negara baru. Sekalipun banyak para pemimpin di negara-negara pasca kolonial mengklaim telah melalui proses penghancuran kolonialisme lewat revolusi, pada kenyataannya banyak dari negara baru itu yang tidak memiliki alternatif lain selain meneruskan sistem lama di mana MHA hanya mengalami transisi dari penindas kolonial ke penindas nasional (baca: negara). MHA di negara pasca-kolonial melewati fase eksploitasi kolonialisme; pengalaman mereka terhadap pelanggaran hak asasi manusia diakibatkan karena proses perampasan sumber daya yang telah mereka manfaatkan secara turun temurun yang dilakukan oleh pihak penjajah. Yang diutamakan dari

13 Pasal 1 ayat (1) Konvensi ILO 169 Tahun 1989 juga mendefinisikan indigenous peoples sebagai "being peoples in independent countries who are regarded as indigenous on account of their descent from population which inhabited the country, or a geographical region to which the country belongs, at the time of conquest or colonization or the establishment of present states boundaries and who, irrespective of their legal status, retain some or all of their own social, economic, cultural and political institution". 
rekognisi hak MHA di wilayah pasca kolonial ialah restrukturalisasi akses MHA itu terhadap ruang hidup mereka.

Sebagaimana pengamatan Shireen Morris dan Noel Pearson, terdapat dua pendekatan rekognisi hak MHA yang bisa ditempuh oleh negara, tetapi tergantung pada pengalaman historis masing-masing. Pertama, pendekatan rekognisi simbolik. Pendekatan ini cenderung memandang pengakuan konstitusional sebagai tindakan utama yang dimaksudkan untuk menciptakan momen rekonsiliasi nasional. ${ }^{14} \mathrm{Tu}$ juan utamanya adalah pengakuan yang memberikan dampak sosial, emosional dan moral bagi MHA yang bersangkutan. Pendekatan ini mengasumsikan bahwa entitas MHA sudah tidak ada (jika ada, populasi mereka mungkin relatif kecil) kecuali keturunan mereka yang telah mengalami akulturasi, asimilasi dan "pemberadaban/westernisasi" oleh pihak kolonial.

Kedua, pendekatan rekognisi praktis. Pendekatan ini menegaskan bahwa tujuan rekognisi ialah merekonstruksi tatanan hukum negara secara lebih adil dan terbuka, menciptakan hubungan kerja yang lebih produktif antara MHA dan negara. ${ }^{15}$ Pendekatan ini umumnya ditempuh lewat jalur reformasi hukum, menetapkan beberapa hak, peraturan, proses, maupun jaminan untuk mengkalibrasi ulang hubungan antara MHA dan negara secara positif. ${ }^{16}$ Pada pendekatan ini diketahui bahwa kedua belah pihak telah memahami betul fungsi konstitusi dan sifat konstitusi yang membatasi kekuasaan pemerintah, mencegah tindakan sewenang-wenang dan melindungi hak dan kebebasan warga negaranya termasuk MHA. Dengan demikian pendekatan ini tampaknya lebih cocok diterapkan di negara-negara yang memiliki tingkat perbedaan kesadaran hukum — antara negara dan masyarakat hukum adat-yang relatif kecil. Di Argentina, rekognisi hak MHA tahun 1994 secara khusus mengangkat istilah pueblo (semacam istilah Marhaen atau kaum miskin dalam kosakata bahasa

14 Shireen Morris dan Noel Pearson, "Indigenous Constitutional Recognition: Paths to Failure and Possible Paths to Success", Journal of Thomson Reuters, 91 (2017), hlm. 350.

15 Morris dan Pearson, "Indigenous Constitutional Recognition”, hlm. 353.

16 Morris dan Pearson, "Indigenous Constitutional Recognition”, hlm. 353. 
Spanyol) sebagai konstituen negara. ${ }^{17}$ Meskipun penggunaan istilah pueblo tidak mesti menyiratkan secara langsung rekognisi hak MHA yang letterlijk, ia memberi referensi bagi penafsiran hukum yang mengarah pada perlindungan dan pengakuan MHA di sana dalam hal yang lebih konkret. ${ }^{18}$

Negara-negara Amerika Latin yang berbahasa Spanyol saat ini umumnya telah melakukan rekognisi hak MHA dengan samasama menggunakan istilah pueblo dalam konstitusi mereka, kendati antara negara satu dengan yang lain memiliki sistem pemerintahan dan kekuasaan yang berlainan sebagai ekpresi keragaman MHA dan tendensi ideologi politik di sana. Sebagaimana dinyatakan Gonzalo Aguilar, Sandra La Fosse, Hugo Rojas, dan Rebecca Steward, fakta bahwa MHA pra-kolonial telah mengontrol dan menguasai wilayah mereka secara turun temurun, mengharuskan negara pasca kolonial memberikan jaminan penentuan nasib sendiri (recognition of selfdetermination), jaminan penentuan hidup sesuai adat istiadat sendiri (usos y costumbres), otonomi pemerintahan sendiri (self-government) sesuai hukum adat lokal, pengembangan kebudayaan sendiri dan jaminan terhadap akses sumber daya. ${ }^{19}$ Kesadaran politik dan hukum semacam ini sebenarnya merupakan fenomena yang relatif baru

17 Konstitusionalisasi konstituen memang merupakan hal yang lazim dalam penulisan konstitusi dan hal ini biasanya menjadi ciri khas yang muncul akibat pengalaman masyarakat. Konstitusi China (1949 dan 1954) menjadikan kelas petani (peasants, bukan farmers) sebagai konstituen negara. Hal ini berhubungan dengan pemikiran marxis-maois China yangmemandangkelas petani proletar sebagai agen revolusi. Konstitusi Bolsheviks Soviet (1921) menjadikan kelas buruh dan petani sebagai konstituennya. Ketika revolusi 1917 berlangsung Kaisar Tsar tengah membimbing Rusia menjadi negara industri, hal ini meningkatkan jumlah kelas buruh proletar yang dianggap sebagai agen revolusi. Di Indonesia, sepertinya yang mesti diselidiki adalah asal usul kata "rakyat" yang digunakan dalam semua Konstitusi Indonesia. Konon istilah rakyat ini merujuk pada lapisan masyarakat kolonial yang paling melarat, yakni kaum bumiputera.

18 Gonzalo Aguilar, Sandra La Fosse, Hugo Rojas, dan Rebecca Steward, "South/North Exchange of 2009, The Constitutional Recognition of Indigenous Peoples in Latin America”, International Law Review Online Companion, 2, 2 (2010), hlm. 51.

19 Aguilar, Fosse, Rojas, dan Steward, “South/North Exchange of 2009”, hlm. 54. 
bagi Amerika Latin yang juga telah menyedot perhatian kaum konstitusionalis. ${ }^{20}$

Dalam pengalaman Amerika Latin abad 20, klaim penguasaan sumber daya agraria di wilayah MHA oleh rezim diktator militer yang didukung Amerika Serikat, barangkali satu-satunya fenomena yang baru bisa dijelaskan kaum konstitusionalis karena faktor sumber daya inilah yang membuka peluang bagi pelanggaran hak asasi manusia MHA di segala aspek. ${ }^{21}$ Oleh sebab itu rekognisi masyarakat hukum adat di Amerika Latin, selain sebagai bentuk penegasan diri atas identitas adat (self affirmation of indigenous identity), juga bermakna sebagai momentum untuk mendestruksi bentuk-bentuk alienasi MHA terhadap ruang hidupnya dari aspek hukum, politik, hubungan internasional dan ekonomi yang luas.

Secara khusus Gonzalo Aguilar, Sandra La Fosse, Hugo Rojas, dan Rebecca Steward mengidentifikasi apa yang mereka sebut sebagai "momentum destruksi" dengan klasifikasi berikut. Pertama, rekognisi konstitusional atas perbedaan kultural (constitutional recognition of cultural diversity). Klasifikasi ini menuntut adanya pengakuan terhadap keragaman budaya oleh negara sebagai elemen struktural dari sistem sosial politik seperti Bolivia yang mendefinisikan dirinya sebagai negara plurinasional. Tiap MHA memiliki otonominya masing-masing dan tidak ada satupun dalih yang membenarkan tindakan hukum dari negara untuk mengenyampingkan otonomi tersebut kecuali melalui proses yang demokratis dan terbuka. Kedua, rekognisi konstitusional atas hak menentukan nasib sendiri secara budaya (constitutional recognition of cultural self determination). Klasifikasi ini menuntut negara mengakui identitas kultural MHA seba-

20 Jose Maria Monzon mencoba menjelaskan fenomena ini sebagai bentuk gerakan konstitusionalisme baru, yaitu suatu fusi antara kepentingan MHA yang merupakan masyarakat mayoritas terutama di Bolivia dan Ekuador, meningkatnya minat kaum progresif terhadap sosialisme sebagai politik alternatif dan meningkatnya kesadaran berkonstitusi. Baca: Jose Maria Monzon, "The Constitution as a Post-Colonial Discourse: An Insight into the Constitution of Bolivia", Seattle Journal for Social Justice, 12, 3 (2014).

21 Nieves, "The Indigenous and the Struggle for Political Representation", hlm. 26. 
gai prasyarat untuk pemenuhan hak kolektif mereka. Rekognisi ini juga diatur dalam Pasal 6 Declaration on the Rights of Indigenous Peoples. Berdasarkan klasifikasi ini masyarakat adat akan memiliki penentuan nasib sendiri atas politik mereka, dan dapat dengan bebas mengejar pembangunan ekonomi, sosial dan budaya mereka. ${ }^{22}$

Ketiga, rekognisi konstitusional atas hukum adat (constitutional recognition of customary law). Klasifikasi ini pertama-tama menuntut adanya pengakuan hukum adat sebagai hukum yang memiliki kekuatan otoritarif bagi masyarakat dalam sudut pandang negara dan kedua rekognisi ini menurut adanya perombakan hukum besar-besaran ke arah pluralisme hukum (dalam tradisi hukum Amerika Latin disebut derechos consetudinarios). Rekognisi ini akan membebaskan MHA terhadap pilihan hukum; membebaskan mereka untuk membangun sistem peradilan pra-kolonial maupun sistem sanksi yang pernah ada (tetapi dengan syarat bahwa sanksi yang diberikan tidak merenggut hak hidup orang lain seperti tradisi persembahan) dan mekanisme resolusi konflik secara adat. ${ }^{23}$ Keempat, rekognisi konstitusional atas hak berpolitik (constitutional recognition of political rights). Negara memberikan rekognisi terhadap hak politik MHA untuk menentukan nasib sendiri terutama melalui pengakuan formal hak MHA dalam sistem politik. Pengalaman Kolombia misalnya mengatur secara tersendiri porsi kursi bagi perwakilan MHA di parlemen. ${ }^{24}$ Kelima, rekognisi konstitusional atas hak mengklaim dan berjuang untuk hak komunal atas tanah, teritori dan sumber daya alam (constitutional recognition of right to claim and fight for collective rights of lands, teritories, and natural resources). ${ }^{25}$ Rekognisi ini dipandang empat sarjana tersebut sebagai elemen paling penting di era kontemporer karena segala macam bentuk pelanggaran hak asasi manusia terhadap klasifikasi

22 Aguilar, Fosse, Rojas, dan Steward, "South/North Exchange of 2009”, hlm. 59.

23 Aguilar, Fosse, Rojas, dan Steward, "South/North Exchange of 2009”, hlm. 86.

24 Aguilar, Fosse, Rojas, dan Steward, “South/North Exchange of 2009”, hlm. 65.

25 Aguilar, Fosse, Rojas, dan Steward, "South/North Exchange of 2009”, hlm. 73. 
kelima akan meluas pada aspek rekognisi lainnya.

Bagi pengalaman negara pasca kolonial selain di Amerika Latin, terdapat kesamaan kondisi historis yang bisa menjadi titik uji komparasi. Pengalaman kolonialisme, segala macam bentuk penghisapan ekonomi dari negara imperial terhadap tanah jajahan merupakan permasalahan kronis bagi MHA di Asia, terutama di Hindia Belanda (Indonesia). Dengan menggunakan klasifikasi yang didasarkan atas pengamatan sarjana konstitusionalis terhadap Amerika Latin, dilakukan identifikasi bagaimana Indonesia mengatur dan mengkonstitusionalisasi hak MHA dari satu konstitusi ke konstitusi berikutnya.

\section{Rekognisi Hak Masyarakat Hukum Adat di Indonesia}

\section{Masa Kolonial}

Meskipun terdapat upaya yang cukup kuat dari kalangan ilmuwan dan politisi progresif berkebangsaan Belanda untuk melindungi kepentingan MHA di wilayah jajahan Hindia Belanda, boleh dikatakan tidak satupun upaya itu yang menawarkan perubahan konkret bagi nasib MHA. Apa yang secara resmi oleh Belanda disebut sebagai bewuste rechtpolitiek 1910, suatu penindasan yang lembut (gentle oppresion), pada dasarnya muncul karena revolusi liberal 1848 yang tengah melanda daratan Eropa di mana gelombang "humanitarian" dari revolusi itu baru sampai di tanah jajahan hampir 50 dekade berikutnya. $^{26}$

Kebijakan tersebut memperjuangkan berlakunya asas concor-

26 Dalam aspek konstitusional dapat diukur pengaruh revolusi liberal tersebut terhadap perubahan Indische Staatsregeling 1854 pada tahun 1918 yang salah satu perubahan itu memberikan kesempatan kepada kaum bumiputera yang tunduk pada hukum adat untuk mengikatkan diri secara sukarela kepada hukum Eropa dalam melakukan kegiatan wiraswasta (enterprise) melalui hak kepemilkan privat. Dalam sektor agraria, Agrarish Wet sendiri sebenarnya telah memberikan kesempatan terhadap kalangan bumiputera untuk memiliki tanah, meskipun pada kenyataannya, sebagaimana dinyatakan Karl Pelzer, jumlah tanah eigendom milik pribumi secara kuantitatif lebih sedikit dibandingkan tanah milik orang Belanda sampai dengan keruntuhan Hindia Belanda tahun 1942. Karl Pelzer, "The Agricultural Foundation", dalam Bruce Glassburner, The Economy of Indonesia Selected Readings (Jakarta: Equinox Pub), hlm. 70. 
dantie beginsel yang berupaya mendudukkan semua golongan (orang Eropa, Timur Asing dan Bumiputera) ke dalam satu hukum positif Eropa. Motif utama dari kebijakan tersebut adalah menjadikan MHA lebih maju, "diberadabkan" seperti bangsa Eropa yang tengah beralih dari corak masyarakat agraris ke masyarakat industrial. Pada kenyataannya kebijakan ini terus mendapat kritik dari sarjana hukum Belanda seperti Cornelis van Vollenhoven dan Ter Haar dengan alasan ilmiah atas penelitian lapangan mereka terhadap MHA. Para sarjana hukum itu berpendapat bahwa MHA memiliki kebutuhan hukum yang tidak dapat disamakan begitu saja dengan orang Eropa dan mereka terikat pada hukum adatnya masing-masing. ${ }^{27}$ Sebagai contoh, hak ulayat (beschikkingrecht [right of allocation]) merupakan hak atas tanah dalam MHA yang telah turun temurun diwariskan yang tidak bisa dipukul rata setara dengan hak atas tanah eigendom. Di kalangan sarjana hukum bumiputera, pandangan semacam ini mendapat sokongan yang kuat karena menyediakan basis pengetahuan untuk mencari tahu susunan hukum adat Indonesia sebelum kolonialisme. Kemunculan klub teosofi Indonesische Studieclub, maupun partai politik seperti Partai Komunis Indonesia, Partai Nasional Indonesia dan Partai Politik Parindra pada tahun 1920-30an mendorong geliat gerakan nasionalis lebih militan dengan minat mencari formatur ideal bagi nation Indonesia merdeka lewat penelusuran sejarah ketatanegaraan adat masa lampau.

27 Kemunculan penelitian-penelitian tentang hukum adat sebenarnya dipicu oleh pertarungan antara kaum partikularis yang dipimpin oleh Scholten van Oud Haarlem melawan kaum universalis yang dipimpin oleh Van der Puute untuk menentukan hukum adat sebagai hukum yang diakui oleh negara kolonial di tanah terjajah. Sejak perdebatan itu terdapat kesadaran yang kuat bahwa apa yang dikenal sebagai adat recht memang benar-benar ada, dan konsep hukum adat ini sama sekali bukan sebuah kumpulan preseden normatif-tertulis sebagaimana konsep hukum Romawi-Jermanik yang dipakai Belanda. Hal ini semakin melemahkan kesan mengenai apa yang selama ini dipandang remeh oleh kaum universalis Belanda tentang hukum adat sebagai produk fantasi kaum Indolog. Penelitian Snouck Hurgronje dan Cornelis van Vollenhoven juga menguatkan pandangan bahwa hukum adat memang betul-betul ada. Baca: Peter Burns, The Leiden Legacy Concepts of Law in Indonesia (Jakarta: Pradnya Parmita, 1995) dan J.F. Holleman, Van Vollenhoven on Indonesian Adat Law (Leiden: KITLV, 1981). 
Pada masa selanjutnya seiring pergantian kekuasaan dari Belanda ke Jepang pada awal tahun 1940-an memicu pencarian yang lebih mendalam terhadap ideal dari hukum adat Indonesia karena gerakan revivalisme intelektual semacam itu sejalan dengan kepentingan Jepang sebagai mercusuar Asia. Pada periode kebangkiatan nasional ini justru merupakan era penuh ketidakpastian di kalangan MHA.

Dari sudut pandang kolonialisme, kecenderungan Cornelis van Vollenhoven dan Ter Haar terhadap dualisme hukum, memiliki manfaat tersendiri bagi Pemerintah Hindia Belanda karena melindungi watak eksploitasi dari ekonomi kolonial terhadap ruang hidup MHA. Sedangkan dari sudut pandang gerakan nasionalis yang disponsori sarjana hukum bumiputera, terdapat dorongan yang cukup kuat untuk meninggalkan hukum adat lantaran muncul keraguan apakah hukum adat memiliki kemampuan untuk menyelesaikan masalah yang besifat nasional di masa Indonesia merdeka.

Pengalaman kolonialisasi demikian terutama pada bidang ekonomi memperlihatkan dengan jelas bagaimana proses penyingkiran dan marjinalisasi MHA dilakukan dan difasilitasi oleh hukum kolonial. Mula-mula, pendapatan yang terus menyusut pada tahun 1830-an nyaris membuat bangkrut Pemerintah sehingga memunculkan kebijakan cultuurstelsel yang mampu mendongkrak pendapatan yang sedang merosot. Metode bercocok tanam represif itu terbukti memporakporandakan wilayah pertanian MHA di Jawa, Sumatera dan Madura seperti paksaan menanam tanaman yang berorientasi ekspor (tebu, perkebunan sawit dan karet) dan pengenalan pengetahuan baru yang bertentangan dengan kaidah-kaidah bercocok tanam MHA. ${ }^{28}$ Dari sudut pandang ketenagakerjaan, pengenalan sistem kerja upahan oleh Koelie Ordonantie (Staadblad No. 133 Tahun 1881) hanya berguna bagi kalangan feodal untuk mengukuhkan status mereka terhadap kasta sosial yang lebih rendah. ${ }^{29}$

28 J.S. Furnivall, Netherlands Indonesia a Study Plural Economy (Cambridge: Cambridge University Press, 2010), hlm. 110.

29 Allegrond, waaropniet door anderenrecht van eigendomwordtbewezen in landsdomein, Pasal 62 Regeeringreglement Volgens het ontwerp van 1818 yang diberlakukan kembali oleh Agrarische Belsuit. 
Kepentingan industri perkebunan swasta (particuliere landenrijen) mendesak Pemerintah Hindia Belanda membentuk bagian penting dalam Agrarisch Wet dan Agrarish Belsuit (Staatsblad No 118 Tahun 1870). Untuk pertama kalinya kedua produk hukum kolonial ini memperkenalkan suatu prinsip hukum domein verklaring yang menganggap bahwa suatu tanah yang tidak dapat dibuktikan kepemilikannya oleh hukum negara dinyatakan sebagai domain negara. ${ }^{30}$ Prinsip ini telah menghilangkan hak atas tanah MHA yang telah turun temurun atas kepentingan industri kapitalis Belanda. J.S. Furnivall memperkirakan sekitar 4,3 juta hektar wilayah MHA yang telah diakuisisi oleh perkebunan Belanda, Inggris dan Amerika Serikat di seluruh wilayah Hindia Belanda antara tahun 1870 sampai 1930an. Beberapa analis seperti John Sutter dan J.H. Boeke menyebutkan bahwa model dualisme hukum yang marak sejak kebijakan etis diberlakukan hanya menguatkan orientasi ganda dari dua kegiatan ekonomi yang saling terpisah antara kegiatan ekonomi subsisten dan ekonomi kapitalis. ${ }^{31}$ Lantaran masyarakat bumiputera berciri beragam etnis yang tunduk pada hukum adat masing-masing dan terus difragmentasi oleh politik devide et impera, konflik agraria kerap mencuat menimbulkan ketegangan antara MHA, negara kolonial, dan korporasi. Bagaimanapun, bagian-bagian utama dari kebijakan dan produk hukum kolonial—baik yang bercorak dualistis maupun kapitalistis-hampir satu abad itu akan sangat menentukan arah perkembangan rekognisi hak MHA pada masa setelah revolusi.

30 Furnivall, Netherlands Indonesia a Study Plural Economy, hlm. 312.

31 J.H. Boeke memprediksi bahwa ekonomi subsisten berangsur-angsur lenyap karena penetrasi modal dari Belanda. Proses pelenyapan ini membentuk apa yang ia sebut sebagai dualisme ekonomi di mana kegiatan ekonomi kapitalis Belanda dan kegiatan ekonomi masyarakat pribumi berlangsung secara terpisah. Teori dualisme ekonomi memang mirip dengan teori dualisme hukum yang diuraikan secara mendalam oleh Van Vollenhoven di mana terdapat dua sistem hukum sekaligus dalam suatu wilayah kekuasaan Hindia Belanda. Lihat J.H. Boeke, Economics and Economic Policy of Dual Societes (Haarlem: Willink \& Zoon, 1953); John. O Sutter, Indonesianisasi: Politics in a Changing Economy, 1940-1955 (Ithaca: Cornell University, Modern Indonesia Project, 1959). 


\section{Pasca Kemerdekaan: Rekognisi dalam UUD NRI 1945}

Tidak ada pegangan yang bisa digunakan untuk memahami rekognisi MHA setelah kemerdekaan selain ketentuan Pasal 18 UUD NRI 1945 yang menyatakan bahwa "Pembagian daerah Indonesia atas daerah besar dan kecil dengan membentuk susunan pemerintahannya ditetapkan dengan Undang-undang dengan memandang dan mengingat dasar permusyawaratan dalam sistem pemerintahan negara, dan hak-hak asal usul dalam daerah-daerah yang bersifat istimewa". ${ }^{32}$ Ketentuan ini jelas merupakan suatu rekognisi konstitusional atas hak politik, kendati pada akhirnya memungkinkan politik penafsiran hukum yang mengerdilkan hak asal usul dalam daerah istimewa lewat UU Pemerintahan Daerah (terutama terjadi di bawah rezim otoriter Demokrasi Terpimpin sampai Orde Baru 1957-1998).

Dalam konteks law making process, Moh. Yamin menyatakan bahwa susunan MHA beserta hukum adat yang berkembang di dalamnya telah dipengaruhi oleh berbagai macam unsur Hinduisme, Islam, termasuk pengaruh feodalisme dan kolonialisme. ${ }^{33}$ Soekarno memandang bahwa prinsip umum "gotong royong" dalam MHA di Indonesia adalah pandangan hidup (weltanschauung) sekaligus berguna sebagai dasar falsafah berdirinya negara (philosofische grondflag). Sejalan dengan itu, Soepomo berupaya memberikan penjelasan tentang hubungan MHA masa lampau dengan rencana pembentukan konstitusi untuk masa depan dengan berulang kali menggarisbawahi pentingnya mengambil bentuk susunan negara modern yang dipelajari dari gagasan fasisme Nazi dan korporatisme Jepang. Sembari

32 Penjelasan Pasal 18 menyebutkan: "Dalam teritori Negara Indonesia terdapat lebih kurang 250 zelfbesturendelandchappen dan volksgemeenschappen, seperti desa di Jawa dan Bali, negeri di Minangkabau, dusun dan marga di Palembang dan sebagainya. Daerah-daerah itu mempunyai susunan asli, dan oleh karenanya dapat dianggap sebagai daerah yang bersifat istimewa. Negara Republik Indonesia menghormati kedudukan daerah-daerah istimewa tersebut dan segala peraturan negara yang mengenai daerahdaerah itu akan mengingati hak-hak asal-usul daerah tersebut.

33 Saafroedin Bahar, Ananda B. Kusuma, dan Nannie Hudawati (ed.), Risalah Sidang Badan Penyidik Usaha-Usaha Persiapan Kemerdekaan Indonesia dan Panitia Persiapan Kemerdekaan Indonesia tanggal 28 Mei 1945-22 Agustus 1945 (Jakarta: Sekretariat Negara Republik Indonesia, 1995), hlm. 18. 
menegaskan kesesuaian asas kekeluargaan dalam MHA Indonesia dengan prinsip hidup gaya timur yang dipraktikkan Jepang, ia menyerukan: ${ }^{34}$

Hak asal usul dalam daerah-daerah yang bersifat istimewa harus diperingati juga. Daerah-daerah yang bersifat istimewa itu ialah pertama daerah kerajaan (kooti), baik di Jawa maupun di luar Jawa, yang dalam bahasa Belanda dinamakan zelfbesturendelanschapen. Kedua, daerahdaerah kecil yang mempunyai susunan asli, ialah dorfgemeinschaften, daerah-daerah kecil yang mempunyai susunan rakyat asli seperti desa di Jawa, nagari di Minangkabau, dusun dan marga di Palembang, huta dan kuria di Tapanuli, gampong di Aceh ... dihormati dengan menghormati dan memperbaiki susunannya asli.

Sederhananya pidato Soepomo di atas merupakan penjelasan untuk mencari susunan asli ketatanegaraan adat Indonesia. Dalam pandangan Soepomo, ideal dasar susunan negara (staatsidee) bagi masyarakat Indonesia bersumber dari riwayat hukum (rechtgeschichte) dan lembaga sosial (sociale structuur) MHA. Hal ini mensyaratkan suatu kesesuaian antara hukum adat Indonesia yang diekstrak menjadi prinsip-prinsip umum untuk diadopsi dalam Konstitusi UUD 1945. Dengan mengajukan suatu konsep "negara integralistik", ${ }^{35}$ alih

34 Bahar, Kusuma, dan Hudawati (ed.), Risalah Sidang Badan Penyidik, hlm. 27.

35 Istilah "negara integralistik" sendiri sebetulnya tidak pernah ditemukan dalam berbagai macam literatur seputar ilmu politik, negara dan filsafat. Soepomo merupakan satu-satunya sarjana yang menggunakan istilah negara integralistik, meskipun dalam menjelaskan apa itu negara integralistik, ia seringkali mengganti istilah integralistik dengan istilah 'totaliter' dan 'organik' yang menurutnya sinonim. Soepomo mengklaim, teori negara integralistik merupakan teori yang dipopulerkan oleh Hegel, Spinoza dan Adam Muller pada abad ke 18 dan 19. Menurut pikiran ini negara tidak untuk menjamin kepentingan seorang atau golongan, akan tetapi menjamin kepentingan masyarakat seluruhnya sebagai persatuan. Menurut Soepomo: 'Suatu susunan masyarakat yang integraal, segala golongan, segala bagian, segala anggota berhubungan erat satu sama lain dan merupakan persatuan masyarakat yang organis. Yang terpenting dalam negara yang berdasar aliran pikiran integral ialah penghidupan bangsa seluruhnya. Negara tidak memihak kepada sesuatu golongan yang paling kuat, atau yang paling besar, tidak menganggap kepentingan seorang sebagai pusat, akan tetapi negara menjamin keselamatan hidup bangsa seluruhnya sebagai persatuan yang tak dapat dipisahkan. Bahar, Kusuma, dan Hudawati (ed.), Risalah Sidang Badan Penyidik, hlm. 33. 
-alih memberi peluang bagi penafsiran hukum yang lebih memihak kepada MHA, tidak ada indikasi dari pasal-pasal dalam UUD 1945 yang mengarah pada rekognisi konstitusional atas hukum adat secara jelas, kecuali bentuk pengadopsian sebagian prinsip hukum adat ke dalam konstitusi nasional. Dalam sektor perekonomian terdapat kesepakatan di antara para perancang konstitusi tentang sistem perekonomian sosialisme negara (staatsocialisme) di mana negara memegang komando perekonomian dan menguasai cabang-cabang produksi dan sumber daya alam di wilayah Indonesia. ${ }^{36}$ Sebagaimana banyak pihak menduga, ketentuan pasal ini agaknya berpotensi besar mengenyampingkan rekognisi konstitusional atas hak komunal tanah, teritori dan sumber daya alam.

Ketika UUD 1945 disahkan, MHA berharap cukup banyak kepada negara untuk segera mengakhiri segala macam bentuk kebijakan dan peraturan yang mengalienasi mereka dari ruang hidupnya. Beberapa upaya yang bisa dilakukan oleh pemerintahan yang belia pada masa revolusi ialah menghapus apa yang dikenal sebagai desa perdikan (frije desa) lewat UU Nomor 13 Tahun 1946 tentang Penghapusan Desa-desa Perdikan. ${ }^{37}$ Penghapusan desa perdikan berarti penghapusan struktur feodal pemerintahan desa yang selama masa kekuasaan kolonial Hindia Belanda telah mengalienasi kepentingankepentingan kaum tani miskin desa dari tata kelola pemerintahan desa yang berkaitan dengan penguasaan sumber daya desa. Pada tahun 1948, ketentuan tentang tanah konversi untuk Yogyakarta dan Surakarta dan selanjutnya tanah-tanah konversi itu dibagikan kepada kaum tani dari MHA melalui program Kasimo Plan. Meskipun langkah ini bisa dikatakan cukup berani dan mendobrak ketika itu, masih banyak tempat di mana MHA bersimpati pada kekuasaan republik belum tersentuh oleh kebijakan yang revolusioner. ${ }^{38}$

36 Pasal 33 UUD 1945.

37 Antara tahun 1912 sampai tahun 1946 ada 170 desa perdikan untuk wilayah Jawa Tengah, Jawa Timur dan Madura. Mochammad Tauhid, Masalah Agraria Sebagai Masalah Penghidupan dan Kemakmuran Rakyat Indonesia (Bogor: STPN Press, 2009), hlm. 207.

38 Wilayah ini merupakan wilayah yang dikuasai oleh gerakan buruh perkebunan komunis dan masyarakat hukum adat seperti di Sumatera 
Pada era demokrasi parlementer Undang-Undang Dasar Sementara 1950 (UUDS 1950), ketentuan rekognisi hak MHA boleh dikatakan cukup memadai daripada Konstitusi pendahulunya UUD 1945 dan Undang-Undang Dasar Republik Indonesia Serikat (UUD RIS). Pasal 104 ayat 1 menyatakan bahwa "Segala keputusan pengadilan harus berisi alasan-alasannya dan dalam perkara hukuman menyebut aturan-aturan undang-undang dan aturan-aturan hukum adat yang dijadikan dasar hukuman itu”. Ungkapan lain yang berhubungan misalnya adalah pernyataan bahwa hak milik memiliki fungsi sosial. Secara politik, kemunculan gerakan masyarakat hukum adat, sebagaimana diungkapkan Herbert Feith, juga mulai tumbuh di bawah rezim demokrasi konstitusional. ${ }^{39}$ Tetapi dalam berbagai eksperimentasi kebijakan agraria di lapangan, sebagian besar kebijakan yang ditujukan kepada MHA untuk menyelesaikan konflik klaim kepemilikan tanah-tanah perkebunan bekas Belanda justru membenarkan pengambilalihan tanah oleh negara dengan menggunakan konsep domeinverklaring (lihat PP Nomor 8 Tahun 1953 tentang Penguasaan Tanah-Tanah Negara). Hal ini hanya menambah daftar panjang konflik agraria antara negara dan MHA akibat pemahaman atas hak milik yang bertolak belakang. Panitia Agraria yang dibentuk tahun 1951 secara gamblang menyatakan bahwa satu-satunya jalan untuk menuntaskan konflik agraria berkepanjangan dari segi perundang-undangan ialah "adanya sistem kepemilikan tanah yang berbasis hukum modern-nasional dengan kombinasi dari hukum adat dan hukum agraria modern, yang mencerminkan spirit bangsa Indonesia". ${ }^{40}$

Kecenderungan terhadap pengambilalihan tanah oleh MHA

Tengah (sekarang Sumatera Utara dan Jambi). Pada tahun 1948 Pemerintah Hindia Belanda mengeluarkan Ordonnantie onrechtmatige occupatie van gronden (staatblad 1948 no. 110) yang memberi sanksi pidana terhadap pendudukan liar lahan-lahan onderneming Belanda. Antara tahun 1945 sampai tahun 1949, okupasi lahan oleh kelompok tersebut telah mencapai lebih dari 10 ribu ha yang terus mendapat dukungan dari elite republik.

39 Herbert Feith, The Decline of Constitutional Democracy (Jakarta: Equinox Publishing, 2007), hlm. 174.

40 Sutter, Indonesianisasi: Politics in a Changing Economy, hlm. 760. 
dengan dasar hak turun temurun terus meningkat ketika atensi politik dalam negeri mendorong tindakan nasionalisasi perusahaan Belanda tahun 1957. Sekalipun hal ini memberikan kesempatan kepada MHA untuk menuntut hak atas tanah mereka kepada negara, terdapat desakan yang kuat, khususnya dari kalangan teknokrat dan militer, untuk mempertahankan kepemilikan tanah bekas Belanda di tangan negara Indonesia demi keberlangsungan kegiatan ekonomi pasca nasionalisasi dan kepentingan nasional yang lebih luas. Negara kini menempatkan berbagai perusahaan negara sebagai penguasa baru atas tanah-tanah yang diklaim MHA sebagai hak mereka.

Situasi yang tidak lebih baik menurut kalangan gerakan MHA juga terjadi pada periode rezim otoriter demokrasi terpimpin. ${ }^{41} \mathrm{Se}$ telah melalui beberapa tahun yang melelahkan pada September 1960, UU Nomor 5 Tahun 1960 tentang Ketentuan Pokok-Pokok Agraria (UUPA) disahkan dan hal ini digadang-gadang akan mengubah lanskap konflik agraria yang melibatkan MHA. Orang tak perlu meragukan bahwa revolusi Indonesia adalah revolusi agraria sebagaimana yang bisa ditemukan dalam pidato emosional Soekarno. UUPA secara khusus mencabut beberapa hukum agraria kolonial yang menjadi sumber utama kesengsaraan MHA yakni Agrarische Wet 1870, Burgerlijk Wetboek buku II, Koninklijk Belsuit 1872 dan prinsip domeinverklaring. Selain itu, dalam perspektif konstitusional, peraturan agraria 1960 - khususnya UUPA - merupakan dokumen hukum pertama yang menguraikan secara sistematis konstitusi ekonomi Pasal 33 UUD 1945.

UUPA menyatakan bahwa hukum agraria nasional didasarkan pada hukum adat. Menurut sarjana hukum nasionalis, hal ini sangatlah penting bagi pembangunan hukum nasional karena kodifikasi hukum adat akan mengakhiri dualisme hukum antara hukum positif kolonial di satu pihak dan hukum adat tanah di lain pihak. ${ }^{42}$ Pasal 5 UUPA menyatakan bahwa "hukum agraria yang berlaku atas

41 Hasil wawancara dengan Syaukani Iksan, peneliti Sayogyo Institute, Malang, 25/11/2017.

42 Ratno Lukito, Legal Pluralism in Indonesia (Oxon: Routledge, 2013), hlm. 65. 
bumi, air dan ruang angkasa ialah hukum adat, sepanjang tidak bertentangan dengan kepentingan nasional dan negara, yang berdasarkan atas persatuan bangsa, dengan sosialisme Indonesia serta dengan peraturan-peraturan yang tercantum dalam undang-undang ini dan dengan peraturan perundangan lainnya, segala sesuatu dengan mengindahkan unsur-unsur yang bersandar pada hukum agama”. Berbagai macam hak atas tanah Pasal 16 ayat (1) — sebagaimana diklaim UUPA — diturunkan dari beberapa macam hukum adat yang relevan, yang bertujuan menyempurnakan ketentuan agraria nasional untuk "kepentingan masyarakat dalam negara modern dan dalam hubungannya dengan dunia internasional, serta disesuaikan dengan sosialisme Indonesia". Karena "kepentingan nasional" merupakan tema yang berkali-kali dinyatakan UUPA, hal ini tentu memiliki makna yang mendalam bagi revolusi Indonesia. Bagaimanapun, kepentingan nasional yang dimaksud ketika itu tidak lain adalah program Pembangunan Semesta Berencana dengan sejumlah alokasi dana pemerintah untuk menciptakan industri berbasis sumber daya agraria dalam negeri.

Kecenderungan UUPA untuk mengutamakan berlakunya hukum positif ketimbang hukum adat, untuk sebagian penjelasannya terletak pada program pembangunan hukum rezim Soekarno dan tradisi pemikiran hukum ketika itu. TAP MPRS No II/MPRS/1960 tentang Manipol USDEK sebagai Garis-Garis Besar Haluan Negara dengan jelas menyatakan bahwa "setiap usaha untuk memperoleh kesatuan hukum harus memperhatikan benar-benar realitas yang ada di Indonesia dan bahwa asas-asas yang dipakai untuk membentuk hukum nasional harus selalu berkesesuaian dengan Garis-Garis Besar Haluan Negara dan harus didasarkan pula pada hukum adat" ${ }^{43}$ Sejalan dengan itu Lembaga Pembinaan Hukum Nasional (LPHN) tahun 1960 yang dibentuk Soekarno, merumuskan arah pembangunan hukum nasional dalam dokumen "Dasar-Dasar dan Asas-Asas Tata Hukum Nasional”. LPHN menyatakan bahwa hukum harus bersifat pengayoman, gotong-royong, kekeluargaan, toleransi, anti-kolonial,

43 Soetandyo Wingjosoebroto, Dari Hukum Kolonial ke Hukum Nasional (Jakarta: HuMa Jakarta, 2014), hlm. 194. 
imperialisme dan feodalisme. Dokumen itu juga menyebutkan bahwa seluruh hukum diupayakan berbentuk tertulis, meskipun selain hukum tertulis diakui juga berlaku hukum tidak tertulis sepanjang tidak menghambat terbentuknya masyarakat sosialis Indonesia. ${ }^{44} \mathrm{Se}$ bagaimana dinyatakan Soebagio Reksodipoero (PNI) kebanyakan hukum adat saat ini tumbuh dalam suasana feodalisme dan kolonialisme, dan oleh sebab itu hukum adat inipun tidak boleh bertentangan dengan sosialisme Indonesia. ${ }^{45}$ Pada umumnya para legislator UUPA memiliki sikap yang sama seperti pernyataan Soebagio Reksodipoero, dan hal tersebut berdampak pada rekognisi terbatas UUPA atas hukum adat.

Dalam cakupan pembaruan hukum secara keseluruhan, pembangunan hukum pada masa itu tidak mungkin dilepaskan dari konteks transformasi tahap pertama yang disebut Roeslan Abdulgani sebagai "pembersihan sisa-sisa pengaruh kolonialisme dan feodalisme dalam bidang hukum” ${ }^{46}$ Suatu kongres Persatuan Sarjana Hukum Indonesia (Persahi) pada tahun 1961 menyatakan komitmennya untuk membina pengembangan hukum sosialis Indonesia, termasuk pada bidang agraria dan menempatkan ilmu hukum dalam fungsinya untuk "meng-tut-wuri-handayani-kan" jalannya revolusi Indonesia dalam mencapai tujuan ekonomi terpimpin. ${ }^{47}$ Dalam kongres tersebut, Sahardjo-Menteri Kehakiman cum akademisi yang mengusulkan pencabutan Burgerlijk Wetboek buku II-menyatakan bahwa hukum adalah alat revolusi; isi peraturan hukum yang dibentuk tidak boleh melempem seakan-akan sama sekali tidak ada sangkut paut dengan

44 Lihat Lampiran A dan B Buku Kelima Sidang Umum MPRS Jilid A-I (Jakarta: MPRS, 1972), hlm. 99-127.

45 Rapat tanggal 1 September 1960, Risalah Sidang Rancangan Undang-Undang tentang Pokok Agraria (tanpa kota: Sekretariat Jenderal Dewan Perwakilan Rakyat Republik Indonesia Pusat Pengkajian dan Pelayanan Informasi Bidang Dokumentasi, tanpa tahun), hlm. 17.

46 Roeslan Abdulgani, Ilmu Hukum dalam Revolusi (tanpa kota: Badan Penerbit Prapantja, tanpa tahun), hlm. 13.

47 Pernyataan Kongres Perhimpunan Sarjana Hukum Indonesia yang Berlangsung di Yogyakarta, 26-30 November 1961, dalam Majalah Perhimpunan Sarjana Hukum Indonesia (Jakarta: Penerbit Djembatan, tahun 1963), hlm. 17. 
tujuan revolusi. Para sarjana hukum adat menyatakan kesediaannya mengadopsi hukum adat, dengan sikap yang agak mendua sejauh tidak bertentangan dengan kepentingan nasional. ${ }^{48}$ Baik LPHN maupun Persahi memprioritaskan kebijakan kodifikasi dan unifikasi hukum yang sesuai dengan kebutuhan industrialisasi Pembangunan Semesta Berencana. Dengan substansi yang sama analisis Depernas menyatakan bahwa beberapa hukum adat di daerah ikut menyulitkan pelaksanaan reforma agraria. ${ }^{49}$

Implikasi hal tersebut sangatlah penting secara teoritis. Pengadopsian konsep negara hukum oleh UUD 1945 memiliki konsekuensi logis, bahwa setiap persoalan kenegaraan mesti memiliki dasar hukum. Dalam UUPA, meskipun hukum adat telah memberi aspirasi bagi restrukturalisasi agraria nasional, karena alasan politik ekonomi untuk memastikan rencana pembangunan dapat berjalan sebagaimana mestinya, maka hukum positif menjadi sangat penting dan diutamakan. Meskipun tidak mengakuinya secara terbuka, atas dasar itulah para legislator UUPA memiliki pandangan yang kuat untuk mengecualikan hukum adat yang menghambat, dan sebagai gantinya mereka memilih secara selektif elemen positif dari hukum barat yang praktis dan cepat untuk program pembaharuan. Bagaimanapun, pengaturan ini berujung pada ketidakpastian terhadap rekognisi hak MHA. Dalam suatu analisa yang kritis atas UUPA, Gouw Giok Siong menyatakan: ${ }^{50}$

The reform of land law is a further step of Indonesia's national government to modernize the indigenous law, and to make it more fit for the economic and social needs of the young Republic as a new member of the community of nations. The basic agrarian law adapts modern principles and works with modern western ideas about title land, such as the distiction between real and personal rights combined with a system of registration to fulfill the requirement of publicity, as

48 M.A. Jaspan, "In Quest of New Law: The Perplexity of Legal Syncretism in Indonesia",Comparative Stuides in Society and History, 7, 3 (1965), hlm. 256.

49 Depernas, Buku Ke-Empat Bidang Kesejahteraan, Pemerintahan dan Keamanan/ Pertahanan Pembangunan Semesta Berencana 1961-1969 (Jakarta: Depernas, tanpa tahun), hlm. 25-29.

50 Gouw Giok Siong, "Law Reform in Indonesia”, Journal of Comparative and International Private Law, 26, 3 (1961), hlm. 547-548. 
these rights have "droit de suite." The registration makes it possible to mortgage the land, and by doing so gives a sound basis for credit system needs for the economic welfare of the country. In the result therefore, the new statute means that the reception of western law will continue in Indonesia. But the western principles are adapted "silently" and without further comment by the legislator.

Kudeta gagal tahun 1965 disusul konflik kekerasan setelahnya sebagian juga dipicu oleh konflik agraria yang tidak terselesaikan antara MHA dan aparatur negara. Rekognisi hak MHA di bawah rezim Orde Baru, meminjam ungkapan aktivis gerakan MHA, mengalami stagnasi berkepanjangan karena rezim itu "lebih kolonial daripada Belanda”. UU Nomor 5 Tahun 1967 tentang Ketentuan PokokPokok Kehutanan dan UU Nomor 11 Tahun 1967 tentang Ketentuan Pokok-Pokok Pertambangan yang diterbitkan untuk memfasilitasi kepentingan swasta dan keuangan negara menyektoralisasikan kewenangan negara untuk memberikan sebagian hak penguasaannya kepada suatu badan usaha yang secara sistematis menyingkirkan sifat populis Pasal 33 UUD 1945. Secara khusus UU Kehutanan menampilkan versi terbaru domeinverklaring dengan memberikan definisi baru terhadap konsep landsdomein melalui kewenangan kepada Menteri Kehutanan untuk menentukan kawasan mana saja yang termasuk kawasan hutan (Pasal 1). Lewat wewenang yang besar itu, Menteri Kehutanan dapat menyatakan bahwa suatu wilayah tertentu-kendati tidak bisa didefinisikan secara ekologis sebagai hutan-dapat dikategorikan sebagai hutan. Dampak paling nyata dari pola penguasaan hutan yang otoritarian tersebut adalah pemberangusan hak-hak MHA. Dengan cara ini, setiap pelaksanaan hak-hak MHA dalam konteks pemanfaatan baik secara langsung atau tidak langsung terhadap sumber daya hutan tidak boleh bertentangan dengan kepentingan yang diakomodasi dalam UU Kehutanan. Hasilnya, pernyataan hutan negara itu justru telah mengalahkan status hak atas hutan adat yang lebih tua ketimbang keberadaan negara termasuk pula kehidupan sosial politik dan kemandirian masyarakat adat. 


\section{Rekognisi dalam Konstitusi Pasca Rezim Otoritarianisme}

Pengalaman di bawah otoritarianisme Orde Baru telah mendorong perenungan besar-besaran terhadap bentuk pelanggaran hak asasi manusia yang dilakukan oleh negara kepada MHA. Tekanan untuk menjadikan MHA sebagai subjek hukum yang terbentuk secara alamiah, bukan dilekatkan oleh negara, melainkan berdasarkan hak asal usul menjadi tuntutan primer dari gerakan MHA tingkat lokal yang diwakili AMAN. Pada tahun 2000 dan 2002, hasil perubahan konstitusi oleh Majelis Permusyawaratan Rakyat (MPR) mengatur secara eksplisit tentang MHA pada empat ketentuan berikut:

Pasal 18B ayat (2) UUD NRI 1945: "Negara mengakui dan menghormati kesatuan-kesatuan masyarakat hukum adat beserta hak-hak tradisionalnya sepanjang masih hidup dan sesuai dengan perkembangan masyarakat dan prinsip Negara Kesatuan Republik Indonesia, yang diatur dalam undangundang".

Pasal 28I ayat (3) UUD NRI 1945: "Identitas budaya dan hak masyarakat tradisional dihormati selaras dengan perkembangan zaman dan peradaban".

Pasal 32 ayat (1) UUD NRI 1945: "Negara memajukan kebudayaan nasional Indonesia di tengah peradaban dunia dengan menjamin kebebasan masyarakat dalam memelihara dan mengembangkan nilainilai budayanya".

Pasal 32 ayat (2) UUD NRI 1945: "Negara menghormati dan memelihara bahasa daerah sebagai kekayaan budaya nasional".

Secara singkat bisa digambarkan bahwa ketentuan Pasal 28I ayat (3), Pasal 32 ayat (1) dan Pasal 32 ayat (2) memenuhi klasifikasi rekognisi konstitusional atas hak menentukan nasib sendiri secara budaya (constitutional recognition of cultural self determination) dan rekognisi konstitusional atas perbedaan kultural (constitutional recognition of cultural diversity), meskipun dalam beberapa hal masih terdapat kecurigaan negara terhadap MHA, seperti kecurigaan yang berlebihan atas ekspresi penegasan diri (self-affirmation) di daerah sebagai ekspresi separatisme..$^{51}$

51 Gerry van Klinken, "Return of the Sultans The Communitarian Turn 
Banyak sarjana hukum Indonesia meragukan bahwa UUD NRI 1945 hasil perubahan telah mengakomodasi tuntutan rekognisi penuh atas hak MHA. Berbeda dari pengalaman Amerika Latin yang melakukan rekognisi penuh, ketentuan dalam Pasal 18B ayat (2) memperlihatkan adanya rekognisi bersyarat (conditional recognition) yang menggunakan pendekatan simbolis. ${ }^{52}$ Sebagaimana dinyatakan Yance Arizona, "pengakuan bersyarat tersebut didasarkan pada kecurigaan yang berlebihan pada MHA; pada satu sisi negara ingin memberikan pengakuan, namun pada sisi lain negara mencurigai hak-hak adat itu dapat mengganggu apa yang disebut sebagai 'kepentingan nasional' yang terkadang dimaknai sebagai pembukaan perkebunan dan hutan secara besar-besaran". ${ }^{53}$ Kepentingan nasional seperti halnya pengalaman Indonesia di bawah rezim Orde Baru senantiasa dimaknai secara ekonomi dan politik. KetentuanPasal 33 UUD NRI 1945 yang tidak terlalu jelas, juga bisa menguatkan berbagai macam agenda neoliberal merugikan MHA.

Putusan MK Nomor 35 / PUU-X/2012 tentang hutan adat telah memberi peringatan bahwa pengakuan dan penghormatan terhadap MHA beserta dengan hak-haknya berdasar Pasal 18B ayat (2) UUD NRI tahun 1945 dapat ditafsir sesuai dengan "kebutuhan" suatu rezim pemerintahan, sehingga MK sebagai Constitution interpreter harus menegasikan isi suatu UU yang merupakan penjabaran dari Pasal dalam Konstitusi. Perlu ada reformulasi teks pada Pasal 18B ayat (2) yang secara nyata mengatur tentang pengakuan dan penghormatan penuh, dengan dasar bahwa kebutuhan hukum dan kebu-

in Local Politics", dalam The Revivial of Tradition in Indonesian Politics the Deployment of Adat from Colonialism to Indigenism, ed. Jamie Davidson dan David Henley (New York: Routledge, 2007), hlm. 158.

52 Terdapat frasa "diatur dalam Undang-Undang" yang berarti tidak mensyaratkan pembentukan UU yang secara khusus mengatur tentang MHA. Hal ini berbeda apabila frasa yang dinyatakan dalam Pasal ini adalah "diatur dengan Undang-Undang".

53 Yance Arizona, "Kelembagaan Negara dan Masyarakat Adat yang Diperlukan untuk Penguatan Hak Konstitusonal Masyarakat Adat", makalah Diskusi Penguatan Pengakuan dan Perlindungan Hak-Hak Masyarakat Adat Guna Restorasi Sosial Indonesia dalam Rangka Ketahanan Nasional, Lembaga Ketahanan Nasional, Jakarta, 1/6/2016. 
tuhan ekonomi serta kebutuhan sosial budaya setiap MHA sangat mungkin berbeda. Standing point dari tulisan ini adalah pemberian hak adat secara penuh dengan tetap mengedepankan prinsip kesatuan dan usaha meningkatkan keadilan sosial bagi setiap warga negara Indonesia.

\section{Kesimpulan}

Pengalaman di negara-negara pascakolonial, khususnya Amerika Latin, menunjukkan bahwa rekognisi hak MHA yang efektif mengandung lima klasifikasi: rekognisi konstitusional atas perbedaan kultural (constitutional recognition of cultural diversity), rekognisi konstitusional atas hak menentukan nasib sendiri secara budaya (constitutional recognition of cultural self determination), rekognisi konstitusional atas hukum adat (constitutional recognition of customary law), rekognisi konstitusional atas hak berpolitik (constitutional recognition of political rights), serta rekognisi konstitusional atas hak mengklaim dan berjuang untuk hak komunal atas tanah, teritori dan sumber daya alam (constitutional recognition of right to claim and fight for collective rights of lands, teritories, and natural resources). Dengan mendasarkan pada lima klasifikasi tersebut disimpulkan bahwa tidak satupun dari Konstitusi yang pernah berlaku di Indonesia secara penuh memberikan pengakuan dan perlindungan terhadap hak MHA dan implementasi dari Konstitusi tersebut yang memenuhi klasifikasi rekognisi hak MHA secara penuh. Format rekognisi bersyarat yang ditempuh Indonesia sekarang justru menimbulkan kendala bagi pemenuhan hak MHA karena sifat yang tidak memaksa negara untuk memenuhi lima klasifikasi rekognisi hak MHA. Interpretasi terhadap pasal-pasal dalam Konstitusi yang mengakui dan memberikan perlindungan terhadap hak MHA harus didasari oleh semangat menegaskan persatuan Indonesia dalam keberagaman dan kekhasan. Interpretasi semacam ini sebenarnya telah diwujudkan, antara lain dalam RUU Pengakuan dan Perlindungan Hak-Hak Masyarakat; namun ketidakjelasan kapan RUU selesai dibahas dan disahkan oleh pemerintah masih menjadi tantangan. Setidaknya usaha rekognisi hak MHA mendekati hasil idealnya. 


\section{Daftar Pustaka}

\section{Artikel/Buku/Laporan}

Abdulgani, Roeslan. Ilmu Hukum dalam Revolusi. Tanpa kota: Badan Penerbit Prapantja, tanpa tahun.

Aguilar, Gonzalo, Sandra La Fosse, Hugo Rojas, dan Rebecca Steward. "South/North Exchange of 2009, The Constitutional Recognition of Indigenous Peoples in Latin America". International Law Review Online Companion, 2, 2 (2010): 44-96.

Arizona, Yance. "Kelembagaan Negara dan Masyarakat Adat yang Diperlukan untuk Penguatan Hak Konstitusonal Masyarakat Adat”. Makalah Diskusi Penguatan, Pengakuan dan Perlindungan Hak-Hak Masyarakat Adat Guna Restorasi Sosial Indonesia dalam Rangka Ketahanan Nasional.Lembaga Ketahanan Nasional, Jakarta, 1/6/2016.

Bahar, Saafroedin, Ananda B. Kusuma, dan Nannie Hudawati (ed.). Risalah Sidang Badan Penyidik Usaha-Usaha Persiapan Kemerdekaan Indonesia dan Panitia Persiapan Kemerdekaan Indonesia tanggal 28 Mei 1945-22 Agustus 1945. Jakarta: Sekretariat Negara Republik Indonesia, 1995.

Boeke, J.H. Economics and Economic Policy of Dual Societes. Haarlem: Willink \& Zoon, 1953.

Burns, Peter. The Leiden Legacy Concepts of Law in Indonesia. Jakarta: Pradnya Parmita, 1995.

Buku Kelima Sidang Umum MPRS Jilid A-I. Jakarta: MPRS, 1972.

Depernas. Buku Ke-Empat Bidang Kesejahteraan, Pemerintahan dan

Keamanan/Pertahanan Pembangunan Semesta Berencana 1961-1969. Jakarta: Depernas, tanpa tahun.

Feith, Herbert. The Decline of Constitutional Democracy. Jakarta: Equinox Publsihing, 2007.

Furnivall, J.S. Netherlands Indonesia a Study Plural Economy. Cambridge: Cambridge University Press, 2010.

Glassburner, Bruce. The Economy of Indonesia Selected Readings. Jakarta: Equinox Pub, 2007.

Holleman, J.F. Van Vollenhoven on Indonesian Adat Law. Leiden: KITLV, 
1981.

Jamie Davidson dan David Henley (ed.). The Revivial of Tradition in Indonesian Politics the Deployment of Adat from Colonialism to Indigenism. New York: Routledge, 2007.

Jaspan, M.A. "In Quest of New Law: The Perplexity of Legal Syncretism in Indonesia”. Comparative Stuides in Society and History, 7, 3 (1965): 252-266.

Klinken, Gerry van. "Return of the Sultans The Communitarian Turn in Local Politics”. Dalam The Revivial of Tradition in Indonesian Politics the Deployment of Adat from Colonialism to Indigenism, diedit oleh Jamie S. Davidson dan David Henley, 149-169. New York: Routledge, 2007.

Komnas HAM. Inkuiri Komnas HAM Hak Masyarakat Hukum Adat atas Wilayahnya di Kawasan Hutan; Buku I. Jakarta: Komnas HAM, 2016.

KPA. Catatan Akhir Tahun 2016: Liberalisasi Diperhebat, Reforma Agraria Dibelokkan. Jakarta: KPA, 2017.

Lukito, Ratno. Legal Pluralism in Indonesia. Oxon: Routledge, 2013.

Maharani, Diah Pawestri. "Pembatasan Hak Menguasai Negara oleh Masyarakat Adat dalam Pengelolaan Sumber Daya Air”. Jurnal Arena Hukum, 9, 1 (2016): 32-52.

Mahkamah Konstitusi. Naskah Komprehensif Perubahan Undang-Undang Dasar Negara Republik Indonesia Tahun 1945 Buku 4 Jilid 2. Jakarta: Mahakamah Konstitusi, 2012.

Majalah Perhimpunan Sarjana Hukum Indonesia. "Pernyataan Kongres Perhimpunan Sarjana Hukum Indonesia”, 26-30/11/1961. Jakarta: Penerbit Djembatan.

Monzon, Jose Maria. "The Constitution as a Post-Colonial Discourse: An Insight into the Constitution of Bolivia”. Seattle Journal for Social Justice, 12, 3 (2014): 821-842.

Morris, Shireen dan Noel Pearson. "Indigenous Constitutional Recognition: Paths to Failure and Possible Paths to Success”. Australian Law Journal, 91, 5 (2017): 350-359.

Nieves, Angelica T. "The Indigenous and the Struggle for Political Representation in Bolivia”. Disertasi, University of South Flori- 
da, 2012. http: / / scholarcommons.usf.edu/ etd/ 4183

Peluso, Nancy Lee. Rich Forest Poor People: Resource Control and Resistance in Java (Hutan Kaya Rakyat Melarat Penguasaan Sumberdaya dan Perlawanan di Jawa). Alih bahasa oleh Landung Simatupang. Yogyakarta: Insist Press, 2006.

Risalah Sidang Rancangan Undang-Undang tentang Pokok Agraria. Tanpa kota: Sekretariat Jenderal Dewan Perwakilan Rakyat Republik Indonesia, Pusat Pengkajian dan Pelayanan Informasi Bidang Dokumentasi, tanpa tahun.

Savitri, Laskmi. "Rentang Batas Dari Rekognisi Hutan Adat dalam Kepengaturan Neoliberal”. Jurnal Wacana, 33, 14 (2014): 61-98.

Siong, Gouw Giok. "Law Reform in Indonesia”, Journal of Comparative and International Private Law, 26, 3 (1961): 535-553.

Sutter, John O. Indonesianisasi: Politics in a Changing Economy, 19401955. Ithaca: Cornell University, Modern Indonesia Project, 1959.

Tauhid, Mochammad. Masalah Agraria Sebagai Masalah Penghidupan dan Kemakmuran Rakyat Indonesia. Bogor: STPN Press, 2009.

United Nation. State of The World Indigenous Peoples. New York: United Nation, 2009.

Webber, Jeffrey R. Red October Left-Indigenous Struggles in Modern Bolivia. Leiden: Brill, 2011.

White, Ben. "Di antara Apologia Diskursus Kritis: Transisi Agraria dan Pelibatan Dunia Ilmiah di Indonesia”. Dalam Ilmu Sosial dan Kekuasaan di Indonesia, diedit oleh Vedi R. Hadizdan Daniel Dhakidae, 119-154. Jakarta: Equinox Publishing, 2006.

Wingjosoebroto, Soetandyo. Dari Hukum Kolonial ke Hukum Nasional. Jakarta: HuMa, 2014.

\section{Hasil Wawancara}

Hasil wawancara dengan Yance Arizona, Direktur Epistema Institute, di Malang, 10/10/2016.

Hasil wawancara dengan Syaukani Iksan, Peneliti Sayogyo Institute, di Malang, 25/11/2017. 